\title{
Genomic Analysis of Plasma Cell-Free DNA in Patients With Cancer
}

\section{Citation}

Oxnard, Geoffrey R., Cloud P. Paweletz, and Lynette M. Sholl. 2016. "Genomic Analysis of Plasma Cell-Free DNA in Patients With Cancer." JAMA Oncology (August 18). doi:10.1001/ jamaoncol.2016.2835.

\section{Published Version}

doi:10.1001/jamaoncol.2016.2835

\section{Permanent link}

http://nrs.harvard.edu/urn-3:HUL.InstRepos:32705580

\section{Terms of Use}

This article was downloaded from Harvard University's DASH repository, and is made available under the terms and conditions applicable to Other Posted Material, as set forth at http:// nrs.harvard.edu/urn-3:HUL.InstRepos:dash.current.terms-of-use\#LAA

\section{Share Your Story}

The Harvard community has made this article openly available.

Please share how this access benefits you. Submit a story.

Accessibility 


\section{VIEWPOINT}

\section{Genomic Analysis of Plasma Cell-Free DNA} in Patients With Cancer

Geoffrey R. Oxnard,
MD
Lowe Center for
Thoracic Oncology,
Dana-Farber Cancer
Institute, Boston,
Massachusetts; and
Department of
Medicine, Brigham and
Women's Hospital,
Boston, Massachusetts.

Cloud P. Paweletz, PhD

Belfer Center for Applied Cancer Science, Dana-Farber Cancer Institute, Boston, Massachusetts.

Lynette M. Sholl, MD Department of Pathology, Brigham and Women's Hospital, Boston, Massachusetts; and Center for Advanced Molecular Diagnostics, Brigham and Women's Hospital, Boston, Massachusetts.

Corresponding Author: Geoffrey R. Oxnard, MD, Lowe Center for Thoracic Oncology, Dana-Farber Cancer Institute, 450 Brookline Ave, D1240, Boston, MA 02215 (geoffrey_oxnard@dfci .harvard.edu).
Technology

The increased importance of cancer genotyping in guiding cancer treatment has created a need for efficient methods for genomic analysis of patients' cancers. This increased dependence on DNA-based tumor genotyping assays (eg, sequencing, polymerase chain reaction $[P C R]$, fluorescence in situ hybridization [FISH]) has triggered a growing interest in the analysis of free-floating DNA present in the blood of patients with cancer-plasma cell-free DNA (cfDNA). Sensitive PCR techniques together with high-throughput nextgeneration sequencing (NGS) technologies have evolved to a point where genetic analysis of cfDNA is possible.

\section{Strengths}

Genotyping of plasma cfDNA is compelling for a number of reasons. ${ }^{1}$ Most importantly, it can noninvasively provide clinically-relevant genomic information that is usually only available after an invasive tumor biopsy procedure. It can be very fast ${ }^{2}-$ the blood specimen is sent directly to a molecular laboratory for DNA analysis, potentially faster than the complex journey of a tumor specimen from scheduled biopsy procedure to pathology review to molecular testing. Plasma genotyping can be highly quantitative, such that measurement of key cancer genes can potentially offer cancer-specific information on the response to therapy. ${ }^{3}$ The method is readily scalable given the relative ease of specimen processing and handling. Finally, plasma specimens do not undergo formalin fixation, resulting in a reduced level of background "noise" compared with analysis of DNA from formalin-fixed tumor specimens.

\section{Limitations}

There are fundamental differences between the genomic analysis of tumor DNA and plasma cfDNA. While a tumor biopsy specimen is enriched for malignant cancer-derived material, a plasma specimen may contain limited representation of the tumor. Even in patients with cancer, plasma cfDNA is comprised predominantly of patient-derived germline DNA, and careful handling of the blood is important to minimize cell lysis and further contamination by germline DNA. In addition, adequacy assessment is a standard part of tumor genotyping, such that a specimen is only studied if tumor content is adequate for the intended assay. In contrast, such adequacy assessments are challenging for plasma cfDNA, and it is entirely possible that a given cfDNA specimen being studied has no cancer-derived DNA present.

\section{Data Generated}

Most cfDNA genotyping assays are designed to be highly sensitive to overcome the challenge of low levels of cancer-derived DNA within plasma. Some cancers may shed very little DNA into circulation because of small size, limited metastatic spread, or other biological factors. As a result, the clinical sensitivity of plasma genotyping (compared with tumor genotyping) has been reported in the range of $60 \%$ to $80 \%$ in patients with advanced cancer. ${ }^{2,4,5}$ Specificity is also very high for most plasma genotyping assays, which is critical because even low false-positive rates can be problematic when testing for relatively rare molecular alterations. If a mutation is present in $5 \%$ of patients tested and a test has a $5 \%$ falsepositive rate ( $95 \%$ specificity), then half of all positive results will be erroneous ( $50 \%$ positive predictive value). It is therefore essential that the expected level of background "noise" is clearly established during assay validation to minimize the risk of false-positive results and maximize specificity. When the false-positive rate approximates $0 \%$, a positive result from plasma cfDNA testing can potentially be used on its own to guide therapy. Negative results may require either repeated plasma testing or a standard tumor biopsy procedure for genotyping.

\section{Alternate Approaches}

There are several types of plasma genotyping assays that are available for the care of patients with cancer, each addressing the challenges of sensitivity and specificity somewhat differently (Table). Allele-specific PCR, widely used for tumor genotyping, uses unique assay design to preferentially amplify a mutant DNA molecule, thus making it detectable over the background noise from wildtype DNA. ${ }^{4}$ Emulsion PCR assays, such as droplet digital PCR or bead-based digital PCR in emulsion, use surfactant technologies to emulsify DNA into thousands of droplets at limiting dilution, resulting in thousands of individual PCR reactions and allowing absolute quantification of the number of mutant and wildtype variants present. ${ }^{2,6}$ While PCR assays have clinically appealing features, including speed and low cost, these evaluate only known genomic alterations, cannot detect complex alterations like gene fusions, and can be difficult to multiplex. Targeted NGS of cfDNA has the potential to overcome these limitations, with multiplexed detection of a range of genomic alterations, but can be limited by false-positive results generated from sequencing artifacts. Through use of molecular barcoding and stringent bioinformatic approaches, plasma NGS is now moving into the clinical 


\begin{tabular}{|c|c|c|c|c|}
\hline \multirow[b]{2}{*}{ Characteristic } & \multicolumn{2}{|l|}{ PCR Assays } & \multicolumn{2}{|l|}{ NGS Assays } \\
\hline & Allele-Specific PCR & Emulsion PCR & $\begin{array}{l}\text { Amplicon-Based } \\
\text { Targeted NGS }\end{array}$ & $\begin{array}{l}\text { Capture-Based } \\
\text { Targeted NGS }\end{array}$ \\
\hline $\begin{array}{l}\text { Variants potentially } \\
\text { detected }\end{array}$ & $\begin{array}{l}\text { Known recurring } \\
\text { mutations }\end{array}$ & $\begin{array}{l}\text { Known recurring } \\
\text { mutations }\end{array}$ & $\begin{array}{l}\text { Any exonic } \\
\text { mutations, copy } \\
\text { number gains }\end{array}$ & $\begin{array}{l}\text { Exonic mutations, } \\
\text { intronic gene fusions, } \\
\text { copy number gains }\end{array}$ \\
\hline Quantitation & $\begin{array}{l}\text { Semiquantitative } \\
\text { (against standard curve) }\end{array}$ & $\begin{array}{l}\text { Absolute or } \\
\text { relative } \\
\text { quantitation, wide } \\
\text { dynamic range }\end{array}$ & $\begin{array}{l}\text { Quantitation of } \\
\text { relative AF, but } \\
\text { vulnerable to PCR } \\
\text { amplification bias }\end{array}$ & $\begin{array}{l}\text { Quantitation of } \\
\text { relative } \mathrm{AF}\end{array}$ \\
\hline Speed and complexity & $\begin{array}{l}\text { Rapid, relatively easy to } \\
\text { interpret }\end{array}$ & $\begin{array}{l}\text { Rapid, relatively } \\
\text { easy to interpret }\end{array}$ & $\begin{array}{l}\text { Potentially rapid, less } \\
\text { complex } \\
\text { bioinformatics }\end{array}$ & $\begin{array}{l}\text { Potentially slower, } \\
\text { more complex } \\
\text { bioinformatics }\end{array}$ \\
\hline Examples & $\begin{array}{l}\text { Cobas (Roche); } \\
\text { therascreen (Qiagen) }\end{array}$ & $\begin{array}{l}\text { Droplet digital PCR } \\
\text { (Biorad); } \\
\text { BEAMing (Sysmex } \\
\text { Inostics) }\end{array}$ & Tam-seq (Inivata) & $\begin{array}{l}\text { Guardant360 } \\
\text { (Guardant); } \\
\text { cancerselect (Personal } \\
\text { Genome Diagnostics) }\end{array}$ \\
\hline
\end{tabular}

Abbreviations: AF, allelic fraction; BEAMing, bead-based digital PCR in emulsions; cfDNA, cell-free DNA; NGS, next-generation sequencing; $\mathrm{PCR}$, polymerase chain reaction. space and can make accurate and precise calls for variants present in less than $1 \%$ of sequencing reads. ${ }^{5}$

\section{Examples of Use}

One intuitive application for plasma genotyping will be for understanding drug resistance. Already, genotyping of plasma cfDNA has become an important supplement to tumor genotyping for the discovery of resistance mechanisms, report of C797S mutations in the epidermal growth factor receptor (EGFR) gene, acquired after resistance to osimertinib in patients with lung cancer. ${ }^{3}$ With repeated biopsy procedures after drug resistance becoming increasingly standard to test for targetable resistance mechanisms, there is potential for plasma genotyping to become a routine part of managing resistant cancers. For example, a retrospective analysis ${ }^{7}$ of the phase I trial of osimertinib in patients with lung cancer suggested excellent clinical outcomes in those who were positive for EGFRT790M mutation in plasma; but in those with negative plasma genotyping, tumor genotyping for EGFRT790M was then needed to identify additional patients who were likely to benefit.

There is also potential for serial plasma genotyping to noninvasively monitor response to therapy and anticipate clinical progression. In cancers with an oncogenic driver mutation (eg, KRAS, EGFR, $B R A F)$, the levels of this mutation in plasma may be representative of tumor burden and metastatic potential. ${ }^{2}$ Future studies will be needed to determine if monitoring of plasma mutation burden contributes to or supersedes standard approaches involving clinical assessment, tumor imaging, and serum tumor markers. The cost of plasma genotyping currently exceeds that of standard serum tumor markers, so it will be crucial to find settings where this approach adds value. The overall promise of plasma genotyping is clear-there is now need for prospective clinical studies to demonstrate the benefit to facilitate broad and appropriate clinical application.

\section{ARTICLE INFORMATION}

Accepted for Publication: May 16, 2016.

Published Online: August 18, 2016. doi:10.1001/jamaoncol.2016.2835.

Conflict of Interest Disclosures: Dr Oxnard has received consulting fees from Ariad, AstraZeneca, Boehringer Ingelheim, Genentech, and Inivata; and has received honoraria from AstraZeneca, Boehringer Ingelheim, and Chugai. Dr Paweletz has received honoraria from BioRAD Laboratories and Clovis Oncology. Dr Sholl has received consulting fees from Genentech. Drs Oxnard and Paweletz are coinventors on a pending Dana-Farber Cancer Institute patent for a device for the noninvasive blood based monitoring of genomic alterations in cancer. No other disclosures are reported.

Funding/Support: This work was supported in part by the Stading-Younger Cancer Foundation and Harold and Gail Kirstein Lung Cancer Research Fund (Oxnard)
Role of the Funder/Sponsor: Funding parties had no role in the preparation, review, or approval of the manuscript or the decision to submit the manuscript for publication.

\section{REFERENCES}

1. Crowley E, Di Nicolantonio F, Loupakis F, Bardelli A. Liquid biopsy: monitoring cancer-genetics in the blood. Nat Rev Clin Oncol. 2013;10(8):472-484.

2. Sacher AG, Paweletz C, Dahlberg SE, et al. Prospective validation of rapid plasma genotyping for the detection of EGFR and KRAS mutations in advanced lung cancer [published online April 7, 2016]. JAMA Oncol. doi:10.1001/jamaoncol.2016 .0173 .

3. Thress KS, Paweletz CP, Felip E, et al. Acquired EGFR C797S mutation mediates resistance to AZD9291 in non-small cell lung cancer harboring EGFR T790M. Nat Med. 2015;21(6):560-562.

4. Douillard J-Y, Ostoros G, Cobo M, et al. Gefitinib treatment in EGFR mutated caucasian NSCLC: circulating-free tumor DNA as a surrogate for determination of EGFR status. J Thorac Oncol. 2014; 9(9):1345-1353.

5. Schwaederle M, Husain $H$, Fanta PT, et al. Detection rate of actionable mutations in diverse cancers using a biopsy-free (blood) circulating tumor cell DNA assay. Oncotarget. 2016;7(9):97079717.

6. Tabernero J, Lenz H-J, Siena S, et al. Analysis of circulating DNA and protein biomarkers to predict the clinical activity of regorafenib and assess prognosis in patients with metastatic colorectal cancer: a retrospective, exploratory analysis of the CORRECT trial. Lancet Oncol. 2015;16(8):937-948.

7. Oxnard GR, Thress KS, Alden R, et al. Association between plasma genotyping and outcomes of treatment with osimertinib (AZD9291) in advanced non-small-cell lung cancer [published online Jun 27, 2016]. J Clin Oncol. doi:10.1200/JCO.2016.66.7162. 